This article was downloaded by: [Bibliotheek Tu Delft]

On: 16 March 2009

Access details: Access Details: [subscription number 908198929]

Publisher Routledge

Informa Ltd Registered in England and Wales Registered Number: 1072954 Registered office: Mortimer House, 37-41 Mortimer Street, London W1T 3JH, UK

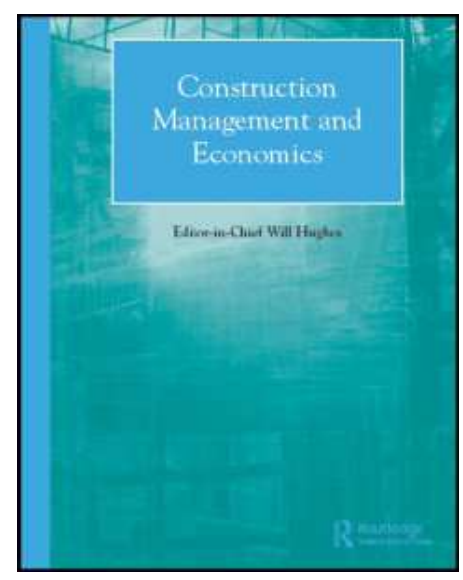

Construction Management and Economics

Publication details, including instructions for authors and subscription information:

http://www.informaworld.com/smpp/title content=t713664979

\title{
The need for customizing maintenance services in social housing
}

Henk-Jan van Mossel a; Ad Straub a

a OTB Research Institute for Housing, Urban and Mobility Studies, Delft University of Technology, Delft, 2628

BX Netherlands

Online Publication Date: 01 January 2009

To cite this Article van Mossel, Henk-Jan and Straub, Ad(2009)'The need for customizing maintenance services in social housing',Construction Management and Economics,27:2,135 - 151

To link to this Article: DOI: $10.1080 / 01446190802695766$

URL: http://dx.doi.org/10.1080/01446190802695766

\section{PLEASE SCROLL DOWN FOR ARTICLE}

Full terms and conditions of use: http://www.informaworld.com/terms-and-conditions-of-access.pdf

This article may be used for research, teaching and private study purposes. Any substantial or systematic reproduction, re-distribution, re-selling, loan or sub-licensing, systematic supply or distribution in any form to anyone is expressly forbidden.

The publisher does not give any warranty express or implied or make any representation that the contents will be complete or accurate or up to date. The accuracy of any instructions, formulae and drug doses should be independently verified with primary sources. The publisher shall not be liable for any loss, actions, claims, proceedings, demand or costs or damages whatsoever or howsoever caused arising directly or indirectly in connection with or arising out of the use of this material. 


\title{
The need for customizing maintenance services in social housing
}

\author{
HENK-JAN VAN MOSSEL* and AD STRAUB \\ OTB Research Institute for Housing, Urban and Mobility Studies, Delft University of Technology, Faffalaan 9, Delft, \\ 2628 BX Netherlands
}

Received 9 January 2008; accepted 16 December 2008

\begin{abstract}
Market segmentation theory is based on the notion that although customers are unique they may be grouped into relatively homogeneous categories which respond in a certain manner to the supplier's marketing efforts. Despite the lack of commercial necessity for the Dutch social rented sector in meeting the demands of tenants, public objectives do compel housing associations to be efficient and effective in maintenance spending. Through customization of maintenance service delivery, the match between users' expectations and the results of maintenance may be improved. Given the limited body of knowledge with respect to preferences of target groups in maintenance of dwellings a post hoc approach is used for this purpose. A large-scale survey was conducted among tenants of large housing associations in the Netherlands. By means of respectively principal component and cluster analyses, customer segments were given shape. Profiling of these segments was achieved through ANOVA and chi-square analyses. There seem to be grounds for housing associations to differentiate, to a limited degree, in their maintenance (purchasing) policy. This, however, always depends on the applicable strategic objectives of the housing association in question.
\end{abstract}

Keywords: Maintenance, service quality, cluster analysis, housing associations.

\section{Introduction}

Maintenance services are a constituent part of the entire housing service, delivered to the customers of the housing association, i.e. the tenants. These maintenance services form the focal objects of the present paper. Dogge (2003) has stressed that maintenance, and more generally, the housing service, has a positive influence on the loyalty of housing associations' customers. Although one may discuss well the real demand consequences, the influence of maintenance on residential satisfaction is significant (Mossel et al., 2006). This expectation was the underlying reason for the research.

The research question is: To what extent is customization of maintenance service delivery useful for housing associations in order to improve user satisfaction about maintenance?

Differentiation in service delivery to customers is an important means to enhance customer satisfaction

*Author for correspondence. E-mail: h.j.vanmossel@tudelft.nl
(Fornell and Johnson, 1993). Indeed, when the service delivery can be adapted to the individual's needs, the perceived quality of the service delivery will be stimulated. The dominant conceptualization suggests service quality is an antecedent of the superordinate satisfaction construct (Brady et al., 2002). Maintenance, primarily outsourced by Dutch housing associations, forms an important part of the housing service. Therefore, differentiating the maintenance service into segments is expected to have positive consequences for satisfaction of housing associations' customers.

In marketing literature, attention is given to the advantages of standardization versus customization of products and services (see e.g. Baalbaki and Malhotra, 1993; Lampel and Mintzberg, 1996; Da Silveira et al., 2001). Market segmentation is presented as a tool to customize products and services while keeping-to a certain extent - the advantages of standardization, e.g. in logistics and cost efficiency. For this reason, market segmentation may be an interesting option for housing associations in putting into practice their customization desires for improving user satisfaction. 
Market segmentation helps decision makers in their product differentiation practices, possibly leading to higher customer satisfaction and loyalty. As maintenance to social housing-but also to commercial housing - is primarily delivered by external service suppliers, results may be translated to maintenance contractors in the purchasing process. More specifically, it may have consequences for the maintenance service specifications, where elements might be directed to specific end-customers, the supplier selection and the configuration of the supplier-client relationship.

Market segmentation is used in this research to check for the feasibility of profiling useful market segments. Given the limited body of knowledge with respect to segmentation in maintenance of dwellings, a post hoc approach was chosen. A large-scale survey was conducted among tenants of large housing associations based in the Netherlands. By means of respectively principal component and cluster analyses, customer segments were given shape. The conclusions focus on the most influential variables shaping customer preferences, with a discussion about the opportunities and barriers for implementation of market segmentation in maintenance service delivery in the Dutch social rented sector.

\section{Literature review}

Market segmentation may be useful to achieve maximum customer satisfaction, while preventing too much effort being given to less important maintenance services or determinants of maintenance service quality for specific market groups. In addition, costs may be reduced by customization of maintenance, for instance because of a decrease of the amount of user complaints. The quality of the process of maintenance does affect both user satisfaction and costs (El-Haram and Horner, 2002).

The services management and marketing literature has largely failed to address the issue of services that play a role in the buying company's customer processes and, in effect, become part of the company's offer to customers (Jackson and Cooper, 1998; Parasuraman, 1998). Nevertheless, Parasuraman argues that customer-seller links differ for services that are used internally and services that will be sold to customers in the next level in the supply chain (whether or not they have been modified). In such supply chains, the quality of the service provision strongly influences endcustomer satisfaction, which implies a need for wellmapped customer requirements (Ahlstrom and Nordin, 2006; Wynstra et al., 2006).
Most often, built asset maintenance is viewed as a cost burden by organizations (Sherwin, 2000; Tsang, 2002). Even in good times, organizations show a reluctance to spend in order to preserve the condition of their assets (Chew et al., 2004). Research in priority setting in maintenance has been focused on the tuning of the available budget taking into account a wide range of factors. Shen et al. (1998) differentiate between effects of various factors such as building status, physical condition and the importance of usage, fabrics and service provision. Shohet (2003) proposes a method enabling the determination of priorities based upon the performance of the entire building and on the performance of each system of the building. Other authors underline the value of maintenance for the business' performance (e.g. Pitt et al., 2006; Jones and Sharp, 2007). But research about the value of maintenance services for different user or tenant groups is lacking.

\section{Objectives of housing associations}

Regardless of the lack of commercial necessity for the Dutch social rented sector in meeting the demands of tenants, public objectives do compel them to be efficient and effective in maintenance spending.

Today, Dutch housing associations are private organizations with public tasks. The public tasks mainly concern the supply of affordable housing and a livable environment to target groups, defined by the central government. Housing associations have to use their own capital to finance the maintenance and renovation of existing housing and they have to find funding for new construction in the capital market (Van Kempen and Priemus, 2002). Despite regulation ex ante and supervision through the Social Housing Management Order (BBSH) and the Housing Act, the Dutch housing association itself is responsible for its goals and the fulfilment of them. Also because each housing association is an individual entity, the mission statement of a particular housing association is not necessarily the same as those that are projected on them from a public perspective.

Maintenance services are an important means to achieve the performances that arise from the two roles of housing associations. First, maintenance influences the quality of real estate and by that the market value of the properties. On the other hand, procuring these services means costs. Concurrently, maintenance services can help in achieving the public and social objectives by affecting the quality of housing and by serving building users in a customer-friendly way (Mossel and Straub, 2007). 


\section{Method}

\section{Context of the study}

This study is focused on maintenance services delivered on behalf of Dutch housing associations to their tenants, the users of the building and its facilities. Dutch housing associations spend over $€ 2.8$ billion annually on the maintenance of their dwellings, excluding capital investments. External service suppliers account for approximately $96 \%$ of this amount (CFV, 2006). The research is based on a questionnaire survey and segmentation of more than 6000 customers of Dutch housing associations. The research focused on planned maintenance and reactive maintenance of both single-family and multi-family dwellings (see Table 1). Planned maintenance is usually conducted for preventive reasons. Reactive maintenance, in contrast, is conducted as a result of damage/breakdown.

The objective of this study is to use theoretically robust social-demographical and geographical variables to identify the characteristics of groups of users with varying opinions about the importance of maintenance services and determinants of service quality.

\section{Questionnaire development}

A survey was conducted among tenants of large Dutch housing associations: Vivare, Vestia, Portaal and Staedion. The survey has been carried out through the use of a questionnaire. The questionnaire consisted of three main components. The first component was directed at measuring relevant social-demographic characteristics of the respondents. The second component included the measurement of both the importance of and the satisfaction about discerned maintenance services, such as maintenance to kitchens, maintenance to communal facilities and maintenance to heating and water systems. The third part of the questionnaire was focused on the measurement of both the importance of and the satisfaction with the discerned determinants of service quality. The definitions of maintenance services have been discussed and sharpened by use of the input of 20 purchasing professionals and other, mostly technical, employees of housing associations, as well as a number of residents of social rented dwellings. The same applies to the definitions of the discerned determinants of service quality, which are originally derived from the SERVQUAL dimensions, developed by Parasuraman et al. $(1985,1988,1991)$ and put into operation.

\section{Sample population}

Around 28000 questionnaires were sent to potential respondents. More than 6000 respondents returned a usable questionnaire. This amounts to a response rate of $22 \%$. In general the representativeness of the conducted research can be considered high, since it closely resembles WBO reference figures, which are generally perceived as representative. ${ }^{1}$ Each selected housing association is located in a specific region. The response rate per housing association-and thus per region-varied between $19 \%$ and $26 \%$. Respondents could fill in the questionnaire either on paper or online; $5.6 \%$ of the response was online and $94.4 \%$ was in writing. The results of both groups are highly comparable. The participating housing associations cover a wide range of cities and towns in the central Netherlands.

Table 1 Maintenance services to building components of single-family dwellings and multi-family houses

\begin{tabular}{|c|c|c|}
\hline & Single-family dwellings & Multi-family houses \\
\hline Structure and exterior envelope & $\begin{array}{l}\text { - Paintwork } \\
\text { - Roofs and gutters } \\
\text { - Hinges and locks of windows and doors }\end{array}$ & $\begin{array}{l}\text { - Paintwork } \\
\text { - Roofs and gutters } \\
\text { - Hinges and locks of windows and doors } \\
\text { - Porches, galleries, corridors, stairways } \\
\text { Balconies }\end{array}$ \\
\hline Interior finishing & $\begin{array}{l}\text { - Bathrooms } \\
\text { - Kitchens } \\
\text { - Toilets }\end{array}$ & $\begin{array}{l}\text { - Bathrooms } \\
\text { - Kitchens } \\
\text { - Toilets }\end{array}$ \\
\hline Electro-mechanical systems & $\begin{array}{l}\text { - Ventilation systems } \\
\text { - Heating and water systems }\end{array}$ & $\begin{array}{l}\text { - Ventilation systems } \\
\text { - Heating and water systems } \\
\text { - Lighting in shared areas } \\
\text { - Lifts }\end{array}$ \\
\hline Peripheral infrastructures & $\begin{array}{l}\text { - Paving around the building } \\
\text { - Drains }\end{array}$ & $\begin{array}{l}\text { - Paving around the building } \\
\text { - Drains } \\
\text { - Communal greenery }\end{array}$ \\
\hline Cleaning & & - Cleaning of shared areas \\
\hline
\end{tabular}




\section{Segmentation}

Market segmentation theory is based on the notion that although customers are unique they may be grouped into relatively homogeneous categories which respond in a certain manner to the supplier's marketing efforts.

Although the objectives of segmentation go largely undisputed, the variety of methods used to achieve it means that, in reality, the term 'segmentation' encompasses a variety of approaches (Wedel and Kamakura, 1998). Essentially, these approaches can be split into (1) a priori, whereby segments are selected from a population in advance based on known characteristics; and (2) post hoc, whereby empirical analysis is used to identify segments (Green and Krieger, 1995).

A wide range of social-demographic and geographic variables has been used to profile the identified segments. Psychographic variables have been left out of this inventory study, since the extensive measurements that are needed in order to get the right information would harm the compactness of the questionnaire and therefore the response rate too much. While including psychographic variables could have resulted in more extensive descriptions of discerned segments, it is not necessary for answering the research question about the usefulness of customization. In subsequent research the segments can be refined using psychographic variables.

\section{Statistical analysis regarding maintenance services}

Before the segmentation analysis was undertaken, a principal component analysis was conducted to identify the smallest number of sets of highly correlated variables and to create a set of components to be treated as uncorrelated variables in the proceeding analysis. The purpose of this sequence is to retain the nature and character of the original variables, as well as to reduce their number to simplify the subsequent multivariate analyses (Hair et al., 1998, p. 95), in this case the cluster analysis. The question whether a tenant rents a single-family dwelling or a dwelling in a multifamily house determines the possible number of maintenance services. Maintenance to communal facilities, for example, is only feasible in multi-family houses. The type of dwelling, therefore, is an objective constraint.

As a result, two groups were initially formed a priori on the basis of those living in single-family dwellings and those living in multi-family houses. For singlefamily dwellings, in total, 10 attributes were subjected to principal component analysis with Varimax rotation. For multi-family houses, this amounts to 16 attributes. This approach was chosen in order to maximize the distinctions between the components. By use of a scree test, the optimum number of components is extracted before the amount of unique variance begins to dominate the common variance structure (Cattell, 1966). Before the scree test was chosen to extract the optimum number of components, trials were conducted with other criteria, such as the Kaiser criterion. The results from the scree test, however, offered us the best representation of the data in components.

For single-family dwellings, two components were generated, representing the constructs of maintenance services inside dwellings and maintenance services outside dwellings. These two components explain $69 \%$ of the variance. Both components were found to have sufficient internal reliability to be subsequently used in the cluster analysis to find naturally occurring homogeneous groups of users (i.e. Cronbach's alpha is 0.95 for maintenance inside dwellings and 0.92 for maintenance outside dwellings). Table 2 shows these components and the component loadings with the defining maintenance services.

For multi-family houses, also two components were generated, now representing constructs of maintenance services basically delivered to individual dwellings and services directed to communal facilities. These two components explain $68 \%$ of the variance. Cronbach's alpha is 0.93 for maintenance basically delivered to individual dwellings and 0.9 for maintenance services directed to communal facilities. Two variables can be perceived exceptional in the generated components. Maintenance to paving around the building is attributed to component 1 , while this is not a maintenance service that is delivered to dwellings in multi-family houses. On the other hand, maintenance to the balcony is attributed to component 2 , while a balcony is seldom a communal facility. Table 2 displays the components with the defining maintenance services.

The variables produced by the principal component analysis were entered into a cluster analysis procedure. The goal of cluster analysis is to identify homogeneous groups of clusters of cases. This is realized by maximizing the distance between groups while simultaneously minimizing the distance within a group. A robust non-hierarchical (K-means) cluster procedure has been applied, as this procedure is able to handle large datasets. In order to choose a satisfactory number of clusters, two criteria were applied. Primarily, the clusters should be logical and easily interpretable from a theoretical perspective. Therefore, in this case, only clearly distinctive couples of component scores were clustered. Secondly, the response per cluster should be sufficient in order to be able to test it for the significance of cluster solutions. 
Table 2 Component loadings maintenance services

\begin{tabular}{|c|c|c|}
\hline \multirow{2}{*}{$\begin{array}{l}\text { Single-family dwellings } \\
\mathbf{n}=\mathbf{1 9 9 8} \\
\text { Maintenance service }\end{array}$} & \multicolumn{2}{|c|}{ Component loadings } \\
\hline & Component 1 & Component 2 \\
\hline $\begin{array}{l}\text { Hinges and locks of } \\
\text { windows and external doors }\end{array}$ & 0.470 & $\underline{0.594}$ \\
\hline Roofs and gutters & 0.322 & 0.764 \\
\hline Bathrooms & 0.809 & $\overline{0.312}$ \\
\hline Ventilation systems & 0.685 & 0.457 \\
\hline Heating and water systems & $\overline{0.673}$ & 0.425 \\
\hline Paving around the building & $\overline{0.322}$ & 0.709 \\
\hline Kitchens & 0.818 & 0.335 \\
\hline Toilets & $\overline{0.831}$ & 0.333 \\
\hline Exterior paintwork & $\overline{0.273}$ & 0.793 \\
\hline Drains & 0.486 & $\overline{0.665}$ \\
\hline
\end{tabular}

\section{Dwellings in}

multi-family houses

$\mathbf{n}=\mathbf{3 1 1}$

\begin{tabular}{|c|c|c|}
\hline Maintenance service & Component 1 & Component 2 \\
\hline $\begin{array}{l}\text { Hinges and locks of } \\
\text { windows and external doors }\end{array}$ & $\underline{0.788}$ & 0.244 \\
\hline Roofs and gutters & 0.733 & 0.105 \\
\hline Bathrooms & $\overline{0.721}$ & 0.426 \\
\hline Ventilation systems & $\overline{0.771}$ & 0.363 \\
\hline Heating and water systems & $\overline{0.738}$ & 0.384 \\
\hline Paving around the building & $\overline{0.678}$ & 0.406 \\
\hline Kitchens & $\overline{0.724}$ & 0.453 \\
\hline Toilets & 0.713 & 0.450 \\
\hline Exterior paintwork & $\overline{0.639}$ & 0.487 \\
\hline Drains & $\overline{0.739}$ & 0.431 \\
\hline Communal greenery & $\overline{0.410}$ & 0.601 \\
\hline $\begin{array}{l}\text { Porch, gallery, corridors and/ } \\
\text { or stairways }\end{array}$ & 0.369 & $\overline{0.817}$ \\
\hline Lighting in shared areas & 0.309 & 0.780 \\
\hline Cleaning of shared areas & 0.311 & 0.810 \\
\hline Lifts & 0.248 & $\overline{0.720}$ \\
\hline Balconies & 0.293 & $\overline{0.747}$ \\
\hline
\end{tabular}

\section{Statistical analysis regarding determinants of maintenance service quality}

Again, principal component analysis was used to identify the smallest number of sets of highly correlated variables and to create a set of components to be treated as uncorrelated variables. For this analysis, no distinction is made between single-family dwellings and multi-family houses. Instead, separate measurements have been made for determinants of service quality of reactive maintenance and planned maintenance. In order to simplify the process of filling in the questionnaire for tenants for determinants of service quality, planned maintenance was equalled to planned maintenance to the exterior building, and reactive maintenance was equalled to reactive maintenance inside dwellings. This way, tenants had one and the same service in mind when answering the various questions, and the duration of the questionnaire was restricted. For both reactive maintenance inside dwellings and planned maintenance to the exterior building, in total, 14 attributes were subjected to principal component analysis with Varimax rotation.

For planned maintenance to the exterior building two components remained. These two components explain $59 \%$ of the variance. These two components represent the constructs that can be described as respectively 'information, courtesy, and quality/tangibles' and '(possible) work and worker-related nuisances'. Both components were found to have sufficient internal reliability to be subsequently used in the cluster analysis to find naturally occurring homogenous groups of users, i.e. Cronbach's alphas are respectively 0.94 (component 1) and 0.85 (component 2). See Table 3.

For reactive maintenance inside dwellings, also two components remained. These two components explain $66 \%$ of the variance. Just as in the case of planned maintenance, the two components represent the constructs that can be described as respectively 'information, courtesy, and quality/tangibles' and 'work and worker-related nuisances'. Both components were found to have sufficient internal reliability to be subsequently used in the cluster analysis to find naturally occurring homogeneous groups of users, i.e. Cronbach's alphas are respectively 0.96 (component 1) and 0.88 (component 2). See Table 3.

The variables produced by the principal component analyses were entered into a cluster analysis procedure. Once the cluster solution was chosen, for both the maintenance services and the determinants of maintenance service quality, the segments were profiled with respect to their stated importance of types of maintenance services (the components) and then compared for significant differences in the essential social-demographic and geographic characteristics.

\section{Segments}

The analysis was carried out to assign subjects iteratively to clusters with the goal of minimizing variability within clusters, while maximizing the variability between clusters. By virtue of the clustering procedure and its use of latent variables created by the component analysis, each of these clusters has a unique profile. After this process of profiling, each segment was given a name to represent its characteristics. These labels are presented in Tables 4 and 5 together with the relative sizes of the clusters. The objective of creating these clusters is thus to define meaningful sub-groups (Wedel and Kamakura, 1998). At its core, it is about reducing the number of entities being dealt with into a 
Table 3 Component loadings determinants of service quality

\begin{tabular}{|c|c|c|}
\hline \multirow{2}{*}{$\begin{array}{l}\text { Planned maintenance to the exterior building } \mathbf{n}=\mathbf{6 0 3 7} \\
\text { Determinant of service quality }\end{array}$} & \multicolumn{2}{|c|}{ Component loadings } \\
\hline & Component 1 & Component 2 \\
\hline Being available to answer questions and receive complaints & $\underline{0.701}$ & 0.249 \\
\hline Flexibility in making appointments & $\overline{0.699}$ & 0.304 \\
\hline Sticking to execution planning agreements & $\overline{0.777}$ & 0.236 \\
\hline Tenant participation in maintenance through options & $\overline{0.501}$ & 0.426 \\
\hline Limiting the time taken by the work & $\overline{0.304}$ & 0.633 \\
\hline Avoiding damage to personal property & $\underline{0.679}$ & $\overline{0.336}$ \\
\hline Having maintenance workers wear smart, uniform overalls & $\overline{0.150}$ & $\underline{0.765}$ \\
\hline Limiting and tidying up litter and dust around the work site & 0.529 & $\overline{0.585}$ \\
\hline Limiting nuisance caused by noise and vibration & 0.173 & $\overline{0.787}$ \\
\hline Being addressed in your own language & 0.254 & $\overline{0.569}$ \\
\hline The competence of maintenance workers & 0.799 & $\overline{0.228}$ \\
\hline The politeness of maintenance workers & $\overline{0.674}$ & 0.414 \\
\hline The quality of the result of maintenance & $\overline{0.849}$ & 0.166 \\
\hline Completing maintenance activities in a single visit & $\overline{0.768}$ & 0.231 \\
\hline \multicolumn{3}{|l|}{ Reactive maintenance inside the dwelling $n=6037$} \\
\hline Determinant of service quality & Component 1 & Component 2 \\
\hline Being available to answer questions and receive complaints & $\underline{0.794}$ & 0.289 \\
\hline Flexibility in making appointments & $\overline{0.749}$ & 0.355 \\
\hline Sticking to execution planning agreements & $\overline{0.827}$ & 0.275 \\
\hline Tenant participation in maintenance through options & $\overline{0.488}$ & $\underline{0.504}$ \\
\hline Limiting the time taken by the work & 0.357 & $\overline{0.653}$ \\
\hline Avoiding damage to personal property & $\underline{0.741}$ & $\overline{0.347}$ \\
\hline Having maintenance workers wear smart, uniform overalls & $\overline{0.130}$ & $\underline{0.786}$ \\
\hline Limiting and tidying up litter and dust around the work site & 0.549 & $\overline{0.583}$ \\
\hline Limiting nuisance caused by noise and vibration & 0.223 & $\overline{0.782}$ \\
\hline Being addressed in your own language & 0.248 & $\overline{0.614}$ \\
\hline The competence of maintenance workers & $\underline{0.837}$ & $\overline{0.254}$ \\
\hline The politeness of maintenance workers & $\overline{0.685}$ & 0.470 \\
\hline The quality of the result of maintenance & $\overline{0.865}$ & 0.172 \\
\hline Completing maintenance activities in a single visit & $\overline{0.785}$ & 0.269 \\
\hline
\end{tabular}

manageable number of groups that are mutually exclusive and share well-defined characteristics (Anable, 2005). In this research, maintenance services clearly differ from each other (from the perspective of users) in the sense that some services are delivered inside dwellings and other outside dwellings in the case of single-family dwellings. In the case of multi-family houses, maintenance services have a different character from the perspective of users when they are delivered to their individual dwelling compared to when they are directed to communal facilities and surrounding infrastructure.

The first step in profiling the service is to examine all the cluster means for the variables used in the profiling. Tables 4 and 5 show the mean component scores for each of the segments that were identified. Component scores are standardized variables with a mean of zero and a variance of one across the sample. These values represent composite ratings on those attitudes that carry essentially the same information in a more compact form (Hair et al., 1998). Each importance rating was scaled from 1 to 7 with higher scores pertaining to a higher importance of a certain aspect for residential satisfaction, perceived by respondents. The component scores follow this pattern. The principal component analyses were carried out using the raw data, the importance ratings. The results of this exercise were the component scores. In the clustering procedure, the components are, again, treated separately from each other. Therefore, Tables 4 and 5 primarily represent relative scores of the discerned clusters on the determined components.

In summary, the population falls into four distinct groups with respect to their scores on the various maintenance services. With respect to the discerned determinants of maintenance service quality, for both planned maintenance and reactive maintenance, the population falls into three distinct groups. The segments display significant differences in the extent to 
Table 4 Mean component scores on variables used to derive the clusters and significant differences for importance of maintenance services

\begin{tabular}{|c|c|c|c|c|}
\hline \multicolumn{5}{|l|}{ Single-family dwellings } \\
\hline Importance of maintenance & $\begin{array}{l}\text { 1. Inside focused } \\
(\mathrm{n}=358)\end{array}$ & $\begin{array}{l}\text { 2. Outside } \\
\text { focused }(n=159)\end{array}$ & $\begin{array}{l}\text { 3. All } \\
\text { maintenance is } \\
\text { important } \\
(n=1149)\end{array}$ & $\begin{array}{l}\text { 4. Other issues are } \\
\text { more important } \\
\text { than maintenance } \\
(\mathrm{n}=332)\end{array}$ \\
\hline \multicolumn{5}{|c|}{ Maintenance inside dwellings } \\
\hline Mean & 0.93 & -1.74 & 0.28 & -1.13 \\
\hline Range & $-0.14-2.81$ & $-5.67--0.56$ & $-0.82-1.11$ & $-5.43--0.99$ \\
\hline \multicolumn{5}{|c|}{ Maintenance to the exterior and outside dwellings } \\
\hline Mean & -1.16 & 1.02 & 0.51 & -1.01 \\
\hline Range & $-4.85--0.12$ & $-0.24-3.45$ & $-0.48-1.57$ & $-4.66-0.09$ \\
\hline \multicolumn{5}{|c|}{ Dwellings in multi-family houses } \\
\hline Importance of maintenance & $\begin{array}{l}\text { 1. Inside } \\
\text { focused }(n=37)\end{array}$ & $\begin{array}{l}\text { 2. All } \\
\text { maintenance is } \\
\text { important } \\
(\mathrm{n}=197)\end{array}$ & $\begin{array}{l}\text { 3. Other issues are } \\
\text { more important } \\
\text { than maintenance } \\
(\mathrm{n}=79)\end{array}$ & \\
\hline \multicolumn{5}{|c|}{$\begin{array}{l}\text { Maintenance services to individual dwellings } \\
\text { (incl. outside) }\end{array}$} \\
\hline Mean & 0.98 & 0.35 & -1.29 & \\
\hline Range & $-0.63-3.18$ & $-1.14-1.24$ & $-4.60--0.15$ & \\
\hline \multicolumn{5}{|c|}{ Maintenance services to communal facilities } \\
\hline Mean & -1.62 & 0.42 & -0.33 & \\
\hline Range & $-4.28--0.41$ & $-0.49-1.58$ & $-4.79-2.04$ & \\
\hline
\end{tabular}

Table 5 Mean component scores on variables used to derive the clusters and significant differences for importance of determinants of service quality

\begin{tabular}{|c|c|c|c|}
\hline \multicolumn{4}{|c|}{ Planned maintenance to the exterior building } \\
\hline Importance of determinants of service quality & $\begin{array}{l}\text { 1. Both process and } \\
\text { results are important } \\
(n=4007)\end{array}$ & $\begin{array}{l}\text { 2. In essence, the } \\
\text { results are important } \\
(n=1372)\end{array}$ & $\begin{array}{l}\text { 3. Other issues are more } \\
\text { important than mainte- } \\
\text { nance }(n=658)\end{array}$ \\
\hline \multicolumn{4}{|l|}{ Information, courtesy, and quality/tangibles } \\
\hline Mean & 0.14 & 0.57 & -2.03 \\
\hline Range & $-1.63-1.20$ & $-1.60-2.91$ & $-7.97--0.69$ \\
\hline \multicolumn{4}{|l|}{ Work and worker-related nuisances } \\
\hline Mean & 0.51 & -1.31 & -0.39 \\
\hline Range & $-0.60-2.12$ & $-6.06--0.22$ & $-3.86-3.17$ \\
\hline \multicolumn{4}{|l|}{ Reactive maintenance inside dwellings } \\
\hline Importance of determinants of service quality & $\begin{array}{l}\text { 1. Other issues are } \\
\text { more important than } \\
\text { maintenance }(n=566)\end{array}$ & $\begin{array}{l}\text { 2. Both process and } \\
\text { results are important } \\
(n=4189)\end{array}$ & $\begin{array}{l}\text { 3. In essence, the results } \\
\text { are important }(n=1282)\end{array}$ \\
\hline \multicolumn{4}{|l|}{ Information, courtesy, and quality/tangibles } \\
\hline Mean & -2.20 & 0.10 & 0.63 \\
\hline Range & $-7.89--0.76$ & $-1.72-1.14$ & $-1.32-2.97$ \\
\hline \multicolumn{4}{|l|}{ Work and worker-related nuisances } \\
\hline Mean & -0.45 & 0.48 & -1.36 \\
\hline Range & $-4.72-1.80$ & $-0.73-2.61$ & $-6.76--0.21$ \\
\hline
\end{tabular}


which they exhibit perceived importance to the discerned aspects.

\section{ANOVA, chi-square}

In order to accept and use a cluster solution, it is necessary to demonstrate the statistical significance and stability (Punj and Stewart, 1983, p. 147). Therefore it is important to know which means are significantly different from each other. By means of ANOVA, combined with post hoc analyses (Scheffe test), and chi-square tests, independent variables that significantly differ between the identified clusters were discerned. The statistical differences with respect to socio-demographic and geographical indicators between the segments are described in Tables 6 and 7. Significant differences identified by the Scheffe and chi-square tests are pointed out in both tables.

\section{Profiles of segments for maintenance services}

The largest segment in the sample, with regard to maintenance services, is the group called 'All maintenance is important'. In the perception of these customers, it is important that the attention of the housing association is directed to all forms of maintenance, i.e. inside, outside, and to communal facilities if applicable. The 'Inside focused' group of customers who are living in single-family dwellings focus on those maintenance services that are delivered inside their dwellings. Customers belonging to the segment called 'Inside focused', living in multi-family houses, find maintenance to their own dwelling more important than maintenance to communal facilities. In contrast, customers belonging to the segment called 'Outside focused', which only appears in case of single-family dwellings, are primarily focused on maintenance to the exterior of their dwelling. Finally, there is a group that can be called 'Other issues are more important than maintenance', which rates all kinds of maintenance as relatively unimportant.

\section{'Inside focused'}

Customers living in single-family dwellings who can be segmented as 'Inside focused' are relatively young. They often live together with their children. They are seldom single. Their education is slightly higher than that of other groups. This is the group with the highest percentage of people earning their income through labour. In general they are unsatisfied with their living situation and with maintenance. 'Inside focused' customers may also live in multi-family houses. Given the restricted response exhibited with regard to residents of multi-family houses, ${ }^{2}$ the amount of significant dependent variables following the analyses is limited. The only significant result from the chisquare analyses is the relatively high percentage of respondents belonging to a non-Western community.

\section{'All maintenance is important'}

The 'All maintenance is important' group of customers comprises the ordinary tenant of the social rented sector. In case of multi-family houses, the people who belong to 'All maintenance is important' are often retired and relatively old. They are relatively satisfied with their living situation. In case of single-family dwellings, more than on average they have lower secondary or vocational education, and fewer people in this group have university or higher vocational education than in other groups. The numbers of hours that they spend outside home for labour is restricted. They are relatively satisfied about their living situation and about maintenance in particular. Since this group of customers rated all questions of the questionnaire as important, conclusions with regards to this group should be considered with care.

\section{'Outside focused'}

This group mainly consists of male customers, although this result is not significant. They are relatively satisfied about both their living situation and maintenance.

\section{'Other issues are more important than maintenance'}

For people living in single-family dwellings, with regard to many aspects this group resembles the group called 'All maintenance is important'. However, they are slightly higher educated than the latter, while satisfaction with their living situation and maintenance is relatively lower. People in multi-family houses do not often have retirement pay. This means that they might work or get e.g. social security payments.

\section{Profiles of segments for determinants of service quality}

From the perspective of the importance of different determinants of maintenance service quality, the largest group that can be discerned is the segment called 'Both process and results are important'. Customers belonging to this segment find aspects of nuisance relatively important (see Table 5). This means that the approach 
Table 6 Characteristics of segments of maintenance services

\begin{tabular}{|c|c|c|c|c|}
\hline \multicolumn{5}{|l|}{ Single-family dwellings } \\
\hline & $\begin{array}{l}\text { 1. Inside } \\
\text { focused } \\
(n=358)\end{array}$ & $\begin{array}{l}\text { 2. Outside } \\
\text { focused } \\
(n=159)\end{array}$ & $\begin{array}{l}\text { 3. All } \\
\text { maintenance is } \\
\text { important } \\
(n=1149)\end{array}$ & $\begin{array}{l}\text { 4. Other issues are } \\
\text { more important } \\
\text { than maintenance } \\
(\mathrm{n}=332)\end{array}$ \\
\hline Gender (\% women) & $52 \%$ & $40 \%$ & $50 \%$ & $49 \%$ \\
\hline Plan to move within 2 years & $15 \%$ & $10 \%$ & $12 \%$ & $14 \%$ \\
\hline \multicolumn{5}{|l|}{ Family income } \\
\hline$<€ 1000$ & $21 \%$ & $13 \%$ & $26 \%$ & $21 \%$ \\
\hline$€ 1000>€ 2000$ & $69 \%$ & $74 \%$ & $63 \%$ & $68 \%$ \\
\hline$>€ 2000$ & $10 \%$ & $13 \%$ & $11 \%$ & $11 \%$ \\
\hline \multicolumn{5}{|l|}{ Source of income:* } \\
\hline Labour & $69 \%$ & $59 \%$ & $50 \%$ & $54 \%$ \\
\hline Retirement pay & $15 \%$ & $25 \%$ & $28 \%$ & $27 \%$ \\
\hline Other allowances and social security payments & $16 \%$ & $17 \%$ & $23 \%$ & $19 \%$ \\
\hline Age (mean)* & 47 & 53 & 54 & 52 \\
\hline \multicolumn{5}{|l|}{ Type of family:* } \\
\hline Single & $14 \%$ & $24 \%$ & $25 \%$ & $28 \%$ \\
\hline Couple without children living at home & $29 \%$ & $35 \%$ & $32 \%$ & $32 \%$ \\
\hline Couple with children living at home & $38 \%$ & $31 \%$ & $28 \%$ & $29 \%$ \\
\hline Single-parent family & $19 \%$ & $11 \%$ & $15 \%$ & $13 \%$ \\
\hline \multicolumn{5}{|l|}{ Community: } \\
\hline Dutch & $92 \%$ & $94 \%$ & $94 \%$ & $96 \%$ \\
\hline Other, Western & $1 \%$ & $1 \%$ & $1 \%$ & $0 \%$ \\
\hline Other, non-Western & $7 \%$ & $4 \%$ & $6 \%$ & $4 \%$ \\
\hline \multicolumn{5}{|l|}{ Education:* } \\
\hline No formal education/elementary school & $5 \%$ & $7 \%$ & $12 \%$ & $9 \%$ \\
\hline Lower secondary/vocational education & $46 \%$ & $46 \%$ & $55 \%$ & $46 \%$ \\
\hline $\begin{array}{l}\text { Higher secondary/intermediate vocational/ } \\
\text { pre-university education }\end{array}$ & $26 \%$ & $30 \%$ & $21 \%$ & $26 \%$ \\
\hline University/higher vocational education & $21 \%$ & $15 \%$ & $10 \%$ & $17 \%$ \\
\hline Other & $3 \%$ & $1 \%$ & $2 \%$ & $1 \%$ \\
\hline \multicolumn{5}{|l|}{ \# of hours of labour/week outside home } \\
\hline \multicolumn{5}{|l|}{ Respondent:* } \\
\hline No job & $22 \%$ & $30 \%$ & $32 \%$ & $28 \%$ \\
\hline$<32$ & $34 \%$ & $20 \%$ & $29 \%$ & $34 \%$ \\
\hline$>32$ & $44 \%$ & $50 \%$ & $39 \%$ & $38 \%$ \\
\hline \multicolumn{5}{|l|}{ Partner of respondent: } \\
\hline No job & $23 \%$ & $26 \%$ & $30 \%$ & $25 \%$ \\
\hline$<32$ & $29 \%$ & $24 \%$ & $24 \%$ & $23 \%$ \\
\hline$>32$ & $48 \%$ & $51 \%$ & $46 \%$ & $53 \%$ \\
\hline \multicolumn{5}{|l|}{ Urbanization: } \\
\hline Low & $17 \%$ & $19 \%$ & $14 \%$ & $15 \%$ \\
\hline Moderate & $49 \%$ & $41 \%$ & $47 \%$ & $50 \%$ \\
\hline Strong & $29 \%$ & $30 \%$ & $32 \%$ & $27 \%$ \\
\hline Very strong & $5 \%$ & $10 \%$ & $7 \%$ & $8 \%$ \\
\hline \multicolumn{5}{|l|}{ Part of country: } \\
\hline Eastern Netherlands & $79 \%$ & $79 \%$ & $79 \%$ & $78 \%$ \\
\hline Western Netherlands & $21 \%$ & $21 \%$ & $21 \%$ & $22 \%$ \\
\hline Year of construction (mean) & 1971 & 1968 & 1967 & 1967 \\
\hline \multicolumn{5}{|l|}{ Satisfaction ( $1=$ very unsatisfied, $7=$ very satisfied $)$} \\
\hline Living situation* & 4.8 & 5.2 & 5.2 & 4.9 \\
\hline Maintenance* & 3.9 & 4.4 & 4.4 & 4.1 \\
\hline Planned maintenance* & 3.7 & 4.2 & 4.2 & 3.9 \\
\hline Reactive maintenance* & 4.5 & 5.0 & 4.9 & 4.5 \\
\hline
\end{tabular}


Table 6 Continued.

\section{Dwellings in multi-family houses}

\begin{tabular}{|c|c|c|c|}
\hline & $\begin{array}{l}\text { 1. Inside } \\
\text { focused } \\
(n=37)\end{array}$ & $\begin{array}{l}\text { 2. Other issues are } \\
\text { more important } \\
\text { than maintenance } \\
(\mathrm{n}=79)\end{array}$ & $\begin{array}{l}\text { 3. All } \\
\text { maintenance is } \\
\text { important } \\
(\mathrm{n}=197)\end{array}$ \\
\hline Gender (\% women) & $57 \%$ & $53 \%$ & $57 \%$ \\
\hline Plan to move within 2 years & $23 \%$ & $27 \%$ & $18 \%$ \\
\hline \multicolumn{4}{|l|}{ Family income: } \\
\hline$<€ 1000$ & $49 \%$ & $25 \%$ & $32 \%$ \\
\hline$€ 1000<€ 2000$ & $42 \%$ & $67 \%$ & $65 \%$ \\
\hline$>€ 2000$ & $9 \%$ & $8 \%$ & $13 \%$ \\
\hline \multicolumn{4}{|l|}{ Source of income:** } \\
\hline Labour & $43 \%$ & $46 \%$ & $35 \%$ \\
\hline Retirement pay & $29 \%$ & $23 \%$ & $44 \%$ \\
\hline Other allowances and social security payments & $29 \%$ & $32 \%$ & $21 \%$ \\
\hline Age (mean)** & 49 & 49 & 57 \\
\hline \multicolumn{4}{|l|}{ Type of family: } \\
\hline Single & $57 \%$ & $63 \%$ & $57 \%$ \\
\hline Couple without children living at home & $17 \%$ & $19 \%$ & $26 \%$ \\
\hline Couple with children living at home & $9 \%$ & $8 \%$ & $10 \%$ \\
\hline Single-parent family & $6 \%$ & $10 \%$ & $7 \%$ \\
\hline \multicolumn{4}{|l|}{ Community:** } \\
\hline Dutch & $77 \%$ & $87 \%$ & $92 \%$ \\
\hline Other, Western & $3 \%$ & & $1 \%$ \\
\hline Other, non-Western & $20 \%$ & $13 \%$ & $7 \%$ \\
\hline \multicolumn{4}{|l|}{ Education: } \\
\hline No formal education/elementary school & $15 \%$ & $13 \%$ & $14 \%$ \\
\hline Lower secondary/vocational education & $33 \%$ & $35 \%$ & $52 \%$ \\
\hline $\begin{array}{l}\text { Higher secondary/intermediate vocational/ } \\
\text { pre-university education }\end{array}$ & $27 \%$ & $24 \%$ & $15 \%$ \\
\hline University/higher vocational education & $18 \%$ & $25 \%$ & $18 \%$ \\
\hline Other & $6 \%$ & $3 \%$ & $2 \%$ \\
\hline \multicolumn{4}{|l|}{ \# of hours of labour/week outside home } \\
\hline \multicolumn{4}{|l|}{ Respondent: } \\
\hline No job & $19 \%$ & $29 \%$ & $29 \%$ \\
\hline$<32$ & $13 \%$ & $9 \%$ & $18 \%$ \\
\hline$>32$ & $69 \%$ & $62 \%$ & $53 \%$ \\
\hline \multicolumn{4}{|l|}{ Partner of respondent: } \\
\hline No job & $26 \%$ & $31 \%$ & $39 \%$ \\
\hline$<32$ & $22 \%$ & $29 \%$ & $25 \%$ \\
\hline$>32$ & $52 \%$ & $40 \%$ & $36 \%$ \\
\hline \multicolumn{4}{|l|}{ Urbanization: } \\
\hline Low & $9 \%$ & $14 \%$ & $12 \%$ \\
\hline Moderate & $26 \%$ & $42 \%$ & $38 \%$ \\
\hline Strong & $46 \%$ & $41 \%$ & $36 \%$ \\
\hline Very strong & $20 \%$ & $4 \%$ & $15 \%$ \\
\hline \multicolumn{4}{|l|}{ Part of country: } \\
\hline Eastern Netherlands & $52 \%$ & $54 \%$ & $48 \%$ \\
\hline Western Netherlands & $49 \%$ & $46 \%$ & $52 \%$ \\
\hline Year of construction (mean) & 1976 & 1977 & 1979 \\
\hline \multicolumn{4}{|l|}{ Satisfaction ( $1=$ very unsatisfied, $7=$ very satisfied $)$} \\
\hline Living situation** & 4.9 & 4.6 & 5.2 \\
\hline Maintenance** & 4.7 & 4.2 & 4.7 \\
\hline Planned maintenance & 4.7 & 4.2 & 4.6 \\
\hline Reactive maintenance** & 4.5 & 4.4 & 5.1 \\
\hline
\end{tabular}

Notes: *Including significant differences $(\mathrm{p}<0.05)$. ${ }^{*}$ Including significant differences $(\mathrm{p}<0.05)$. 
Table 7 Characteristics of segments of determinants of service quality

\begin{tabular}{|c|c|c|c|}
\hline \multicolumn{4}{|l|}{ Planned maintenance to the exterior building } \\
\hline & $\begin{array}{l}\text { 1. Both process } \\
\text { and results are } \\
\text { important } \\
(\mathrm{n}=4007)\end{array}$ & $\begin{array}{l}2 . \text { In essence, } \\
\text { the results are } \\
\text { important } \\
(\mathrm{n}=1372)\end{array}$ & $\begin{array}{l}\text { 3. Other issues are } \\
\text { more important } \\
\text { than maintenance } \\
(\mathrm{n}=658)\end{array}$ \\
\hline Gender ( $\%$ women $)^{*}$ & $52 \%$ & $50 \%$ & $47 \%$ \\
\hline Plan to move within 2 years* & $14 \%$ & $18 \%$ & $16 \%$ \\
\hline \multicolumn{4}{|l|}{ Family income:* } \\
\hline$<€ 1000$ & $30 \%$ & $22 \%$ & $28 \%$ \\
\hline$€ 1000>€ 2000$ & $61 \%$ & $67 \%$ & $64 \%$ \\
\hline$>€ 2000$ & $9 \%$ & $11 \%$ & $8 \%$ \\
\hline \multicolumn{4}{|l|}{ Source of income:* } \\
\hline Labour & $40 \%$ & $59 \%$ & $45 \%$ \\
\hline Retirement pay & $40 \%$ & $21 \%$ & $35 \%$ \\
\hline Other allowances and social security payments & $21 \%$ & $21 \%$ & $20 \%$ \\
\hline Age (mean)* & 57 & 50 & 55 \\
\hline \multicolumn{4}{|l|}{ Type of family:* } \\
\hline Single & $41 \%$ & $34 \%$ & $36 \%$ \\
\hline Couple without children living at home & $32 \%$ & $26 \%$ & $32 \%$ \\
\hline Couple with children living at home & $17 \%$ & $25 \%$ & $20 \%$ \\
\hline Single-parent family & $11 \%$ & $15 \%$ & $11 \%$ \\
\hline \multicolumn{4}{|l|}{ Community:* } \\
\hline Dutch & $93 \%$ & $94 \%$ & $89 \%$ \\
\hline Other, Western & $1 \%$ & $1 \%$ & $1 \%$ \\
\hline Other, non-Western & $7 \%$ & $6 \%$ & $10 \%$ \\
\hline \multicolumn{4}{|l|}{ Education:* } \\
\hline No formal education/elementary school & $16 \%$ & $8 \%$ & $16 \%$ \\
\hline Lower secondary/vocational education & $55 \%$ & $41 \%$ & $46 \%$ \\
\hline $\begin{array}{l}\text { Higher secondary/intermediate vocational/pre-university } \\
\text { education }\end{array}$ & $18 \%$ & $27 \%$ & $22 \%$ \\
\hline University/higher vocational education & $9 \%$ & $22 \%$ & $15 \%$ \\
\hline Other & $3 \%$ & $2 \%$ & $2 \%$ \\
\hline \multicolumn{4}{|l|}{ \# of hours of labour/week outside home } \\
\hline \multicolumn{4}{|l|}{ Respondent:* } \\
\hline No job & $31 \%$ & $21 \%$ & $30 \%$ \\
\hline$<32$ & $27 \%$ & $34 \%$ & $31 \%$ \\
\hline$>32$ & $42 \%$ & $45 \%$ & $39 \%$ \\
\hline \multicolumn{4}{|l|}{ Partner of respondent:* } \\
\hline No job & $26 \%$ & $19 \%$ & $30 \%$ \\
\hline$<32$ & $18 \%$ & $26 \%$ & $21 \%$ \\
\hline$>32$ & $56 \%$ & $55 \%$ & $49 \%$ \\
\hline \multicolumn{4}{|l|}{ Urbanization: } \\
\hline Low & $14 \%$ & $15 \%$ & $15 \%$ \\
\hline Moderate & $43 \%$ & $42 \%$ & $41 \%$ \\
\hline Strong & $31 \%$ & $33 \%$ & $31 \%$ \\
\hline Very strong & $13 \%$ & $11 \%$ & $13 \%$ \\
\hline \multicolumn{4}{|l|}{ Part of country: } \\
\hline Eastern Netherlands & $65 \%$ & $67 \%$ & $65 \%$ \\
\hline Western Netherlands & $35 \%$ & $33 \%$ & $35 \%$ \\
\hline Year of construction (mean) & 1969 & 1966 & 1967 \\
\hline \multicolumn{4}{|l|}{ Satisfaction $(1=$ very unsatisfied, $7=$ very satisfied $)$} \\
\hline Living situation* & 5 & 5.1 & 4.7 \\
\hline Maintenance* & 4.4 & 4.2 & 4.1 \\
\hline Planned maintenance* & 4.3 & 4.1 & 4 \\
\hline
\end{tabular}


Table 7 Continued.

\section{Reactive maintenance inside dwellings}

Gender (\% women)**

Plan to move within 2 years**

Family income:**

$$
\begin{aligned}
& <€ 1000 \\
& € 1000-2000 \\
& >€ 2000
\end{aligned}
$$

Source of income:**

Labour

Retirement pay

Other allowances and social security payments

Age (mean)**

Type of family:**

Single

Couple without children living at home

Couple with children living at home

Single-parent family

Community:**

Dutch

Other, Western

Other, non-Western

Education:**

No formal education/elementary school

Lower secondary/vocational education

Higher secondary/intermediate vocational/pre-university education

University/higher vocational education

Other

\# of hours of labour/week outside home

Respondent:**

No job

$<32$

$>32$

Partner of respondent:**

No job

$<32$

$>32$

Urbanization:**

Low

Moderate

Strong

Very strong

Part of country:

Eastern Netherlands

Western Netherlands

Year of construction (mean)**

Satisfaction ( $1=$ very unsatisfied, $7=$ very satisfied $)$

Living situation**

Maintenance**

Reactive maintenance**
1. Other issues
are more important

than maintenance

$(\mathrm{n}=566)$

$45 \%$

$17 \%$

$28 \%$

$65 \%$

$7 \%$

$42 \%$

$34 \%$

$25 \%$

54

$37 \%$

$32 \%$

$21 \%$

$11 \%$

$89 \%$

$1 \%$

$10 \%$

$14 \%$

$50 \%$

$22 \%$

$12 \%$

$2 \%$

$34 \%$

$27 \%$

$39 \%$

$32 \%$

$19 \%$

$50 \%$

$14 \%$

$42 \%$

$29 \%$

$14 \%$

$64 \%$

$36 \%$

1964
2. Both process

and results are

important

$(\mathrm{n}=4189)$

$52 \%$

$14 \%$

$30 \%$

$61 \%$

$9 \%$

$40 \%$

$39 \%$

$21 \%$

57

$40 \%$

$31 \%$

$18 \%$

$11 \%$

$93 \%$

$1 \%$

$7 \%$

$16 \%$

$54 \%$

$17 \%$

$10 \%$

$3 \%$

$31 \%$

$27 \%$

$42 \%$

$26 \%$

$19 \%$

$56 \%$

$14 \%$

$43 \%$

$30 \%$

$13 \%$

$65 \%$

$35 \%$

1969
3. In essence, the results are important $(\mathrm{n}=1282)$

$51 \%$

$18 \%$

$21 \%$

$68 \%$

$11 \%$

$60 \%$

$21 \%$

$19 \%$

49

$35 \%$

$27 \%$

$25 \%$

$14 \%$

$93 \%$

$1 \%$

$6 \%$

$7 \%$

$41 \%$

$29 \%$

$22 \%$

$2 \%$

$21 \%$

$35 \%$

$44 \%$

$20 \%$

$25 \%$

$55 \%$

$15 \%$

$40 \%$

$34 \%$

$11 \%$

$66 \%$

$34 \%$

1965

Notes: ${ }^{*}$ Including significant differences $(\mathrm{p}<0.05)$. ${ }^{* *}$ Including significant differences $(\mathrm{p}<0.05)$.

$\begin{array}{lll}4.7 & 5 & 5.1 \\ 4.1 & 4.4 & 4.3 \\ 4.5 & 4.9 & 4.7\end{array}$


at the workplace is very important for these customers. Customers belonging to the segment 'In essence, the results are important' find aspects that are related to information, courtesy, and quality/tangibles important, more than work and worker-related nuisances. The third and smallest group, 'Other issues are more important than maintenance', rate the determinants of maintenance service quality in general less important than other groups do.

\section{'Both process and results are important'}

This group of customers contains a relatively high number of retired people. Fewer than on average have children. Fewer than on average have labour as their source of income. They are slightly lower educated than other groups. For reactive maintenance inside dwellings, they are more positive than other groups about the maintenance service, and in general, they are relatively positive about their living situation.

\section{'In essence, the results are important'}

This segment consists of people with slightly higher income than other people in the social rented sector and relatively high education. They are relatively young and children are often included in the family. Most of the people have a job (often full time), and only a small number of people get retirement pay. Slightly more than other segments, they have plans to move soon. Still, they are satisfied with their current living situation.

\section{'Other issues are more important than maintenance'}

People belonging to this group of customers are slightly more than on average male. They relatively often belong to a non-Western community. This is the group with a slightly lower satisfaction about their living situation and the maintenance service than other groups.

\section{Results from analyses}

The present research shows that for single-family dwellings, four segments can be identified. Although segments may be identified, the differences between the segments are restricted. This implies that the results should be considered prudently. The segments differentiate in the perceived importance of maintenance delivered inside dwellings, and maintenance services outside dwellings. The conclusion can be that there seems to be a group of working families, slightly younger than on average, which is primarily focused on maintenance inside their own dwelling. However, there is a group of relatively old people, who, different from the previous group, is relatively satisfied with its living situation and with maintenance in particular, and which is focused on maintenance to the exterior of the building or outside the dwelling. Two other groups of customers do not differentiate in the perceived importance of maintenance in the way the two described groups do. There is a group of relatively satisfied, nonworking, low educated people that find everything important. How this group should be approached is questionable; results might be 'polluted' with some kind of indifference with regard to questionnaire questions. The same applies to its counterpart. People belonging to this group perceive maintenance as less important than does the previous mentioned group; however, like that group they do not differentiate between different maintenance services. The latter group is more highly educated than the group called 'All maintenance is important', while satisfaction with their living situation and maintenance is relatively lower.

For multi-family houses, also four segments can be identified. 'Inside focused' customers, who are focused on maintenance to their individual dwelling, are relatively satisfied about maintenance. The group of customers that is focused on maintenance to communal facilities of the building is, in contrast, relatively unsatisfied with maintenance. Just like the situation of single-family dwellings, two groups of 'indifferent' people can be identified as well.

With regard to determinants of service quality, the discerned segments for planned maintenance to the exterior of the building on the one hand, and reactive maintenance inside the dwelling on the other hand are highly comparable. Segments differentiate in the perceived importance of work and worker-related nuisances, and the perceived importance of issues such as information, courtesy and issues related to the result of the works. One group called 'In essence, the results are important' is primarily interested in high quality information, courtesy and high quality results, while work and worker-related nuisances are much less important to them (see Table 5). Belonging to this group are families with relatively high income and high education. Although they are satisfied with their living situation, they relatively often have plans to move. The group called 'Both process and results are important' consists of people who do value the restriction of work and worker-related nuisances. These people are relatively often retired and living alone, and have low income and education. They are positive about their living situation and about the maintenance service. Finally, like in case of the differentiation to different 
maintenance services, there is a group called 'Other issues are more important than maintenance', consisting of people who are more than on average retired, relatively low educated, often male and relatively often belonging to a non-Western community. They are relatively unsatisfied with their living situation and maintenance in particular.

\section{Limitations of market segmentation}

The ultimate test of a set of clusters is its usefulness (Mitchell, 1994, p. 11). Therefore the practical implications of the analyses will be discussed now. Putting into practice the results from this research may be effectuated in different ways:

(1) Demands with regard to service suppliers could be adapted to the discerned segments, e.g. through specifications and the supplier selection practices;

(2) End-customers could be given the opportunity to give shape to their own service quality demands. This could be done by giving them options of choice in maintenance. In exchange for a fee, additional attention to specific maintenance services or to specific determinants of service quality may be 'bought'. Giving tenants the right to select their own maintenance contractors, like owner-occupiers, is another even more far-reaching method in giving users options of choice.

For both ways, pricing policy should be evaluated thoroughly beforehand. Differentiation may mean less buying power and more need for mutual tuning between supplier and buyer, and thereby entail additional costs. Moreover, in particular for multi-family houses, it may be costly and impracticable to separate dwellings from the rest of the building.

Moreover it is important to acknowledge that housing associations like other businesses have to deal with different objectives for maintenance, i.e. directed to value, sustainability or liveability of the neighbourhood. Therefore maximizing customer satisfaction is never a stand-alone objective. This limits or at least changes the possibilities for differentiation.

\section{Possibilities for customizing maintenance services}

Dutch housing associations are private organizations with public objectives. In practice this implies that housing services are both delivered to special target groups (e.g. low income groups) and to other target groups such as middle income groups of residents. In particular for the latter, it is possible to establish an upgraded service level, as these groups may be more willing to pay for this.

Housing associations in the Netherlands are obliged to comply with the technical building and maintenance regulations. The technical building regulations in the Netherlands are laid down in the Building Decree. The Decree contains the minimal technical building requirements that are deemed necessary from a public viewpoint and have to be complied with by anyone undertaking construction activities in the Netherlands. A basic level of quality of housing, therefore, is created. The National Tenant Committee made a defect list related to the Building Decree and Rent Decree of Housing. If houses have one or more defects the rent can be reduced. In addition, when maintenance is inadequate in the longer term, municipalities may summon housing associations to improve maintenance. These regulations limit the ability of housing associations to determine their own levels of maintenance. However, they do not limit the possibilities for upgrading service levels above the basic level. Furthermore, maintenance services as cleaning of shared areas and maintenance of communal greenery are not regulated at all.

In addition to the regulatory demands related to the Building Decree, housing associations have certain responsibilities in maintenance towards tenants. These responsibilities are set out in the 'Besluit kleine herstellingen' [Small repairs decree] (2003), derived from the Dutch Civil Code (7:240). In general, tenants are responsible for small repairs. Tenants' obligations regarding maintenance are conditional on the accessibility of the building component to be repaired, and restricted costs related to the repair. All other repairs fall within the housing association's responsibility, with the exception of adaptations and additions made by tenants, and defects that are resolved by tenants. The tenant may ask a housing association to perform small repairs that fall under the tenant's responsibility. In that case, the housing association is allowed to charge the tenant for the costs of making these repairs. This is called 'service maintenance'.

Table 8 gives an overview of the regulatory demands in the Dutch context regarding maintenance services.

All the same, while sometimes the possibilities of options of choice regarding the results of maintenance may be restricted, for the process of maintenance, a housing association is seldom restricted by regulatory demands in its optimization possibilities.

The fact that tenants belonging to a certain segment may be scattered all over the properties of a housing association might be a hindrance to segmentation, 
Table 8 Minimum regulatory demands with regards to maintenance services

\begin{tabular}{|c|c|}
\hline Maintenance service & Minimum regulatory demands \\
\hline $\begin{array}{l}\text { Hinges and locks of windows and external } \\
\text { door }\end{array}$ & $\begin{array}{l}\text { The outside door must be lockable and self-closing (BD) } \\
\text { Hinges and locks should function well (DF) }\end{array}$ \\
\hline Roofs and gutters & No leakages (DF) \\
\hline Bathrooms & $\begin{array}{l}\text { Demands regarding the presence, accessibility, physical condition and size (BD } \\
\text { and DF) }\end{array}$ \\
\hline Ventilation systems & $\begin{array}{l}\text { Demands regarding the presence and capacity, flow movement, the quality of air } \\
\text { and physical condition (BD and } \mathrm{DF} \text { ) }\end{array}$ \\
\hline Heating and water systems & $\begin{array}{l}\text { Demands regarding the presence, the available connection with the distribution } \\
\text { channel, the hygienic and physical condition (BD and } \mathrm{DF})\end{array}$ \\
\hline Paving around the building & No subsidence (DF) \\
\hline Kitchens & $\begin{array}{l}\text { Demands regarding the presence, accessibility, physical condition and size (BD } \\
\text { and DF) }\end{array}$ \\
\hline Toilets & $\begin{array}{l}\text { Demands regarding the presence, accessibility, physical condition and size (BD } \\
\text { and DF) }\end{array}$ \\
\hline \multicolumn{2}{|l|}{ Exterior paintwork } \\
\hline Drains & $\begin{array}{l}\text { There must be a connection between the drains and the sewer system (BD) } \\
\text { No leakages (DF) }\end{array}$ \\
\hline \multicolumn{2}{|l|}{ Communal greenery } \\
\hline Porch, gallery, corridors, and/or stairways & $\begin{array}{l}\text { No leakages }(\mathrm{DF}) \\
\text { Demands regarding usability (puddles) and safety of use (DF) }\end{array}$ \\
\hline Lighting in shared areas & $\begin{array}{l}\text { One must be able to leave the building safely (BD) } \\
\text { Demands regarding the physical condition and intensity of light (DF) }\end{array}$ \\
\hline $\begin{array}{l}\text { Cleaning of shared areas } \\
\text { Lifts }\end{array}$ & \\
\hline Balconies & $\begin{array}{l}\text { Demands regarding the strength of the construction (BD) } \\
\text { Demands regarding usability (puddles) and safety of use (DF) }\end{array}$ \\
\hline
\end{tabular}

Notes: $\mathrm{BD}=$ Building Decree, 2002. $\mathrm{DF}=$ Defect list of the National Tenant Committee, Rent Decree of Housing, 2004.

especially for planned maintenance to the structure and exterior, and peripheral infrastructures. As reactive maintenance is often delivered to individual tenants, adapting the service to these individuals is easier. Housing associations should evaluate the possible cost advantages that may come along with bundling user preferences in reactive maintenance, compared to anticipating individual preferences with regard to the desired service level. Housing associations may bundle an upgraded service of reactive maintenance with performing small repairs that fall under the tenant's responsibilities in exchange for a fee.

\section{Conclusions}

There seem to be grounds for housing associations to differentiate, to a limited degree, in their maintenance (purchasing) policy. This, however, always depends on the applicable strategic objectives of the housing association in question.

Active families, slightly younger than on average, do relatively often belong to the group of customers 'Inside focused'. They are in particular interested in high-level maintenance inside their dwellings. They may be allowed to choose a higher level for maintenance inside their dwelling in exchange for a fee. This is, however, a service option that housing associations could offer, without needing to know the customer segments. They can just offer it to individual customers. The knowledge of market segments would just help them to reach the groups of customers concerned to let them know maintenance services. For other situations, segments are of greater help. In the case of planned maintenance to communal facilities, it is impossible to react to individual preferences. Elderly customers, for instance, comprise a group that merits special service treatment. In order to keep these users satisfied it makes sense to provide planned maintenance with relatively high service levels (to an upgraded price). In the latter situation, the use of segments enables more effective maintenance spending.

In general, it is striking that the results for planned maintenance to the exterior of buildings are highly comparable to the results for reactive maintenance inside dwellings, leading to the conclusion that housing associations do not have to differentiate between reactive maintenance and planned maintenance with regard to possible identification of target groups of policy. This lays the foundation for a comprehensive maintenance policy, 
which is advantageous because it facilitates bundling types of maintenance, and, more broadly, a coordinating maintenance policy. In turn, these coordinated (and bundled) maintenance efforts lead to lower total costs of ownership and restricted nuisance of tenants (Mossel, 2008), and improved sustainability because of improvements in maintenance efficiency.

The sample of people living in multi-family houses, and enjoying all types of maintenance is small, leading to a limited scope of conclusions that can be drawn for certain groups of customers. Further research is necessary in order to get more clear profiles of maintenance priorities for customers living in multifamily houses. Moreover, further research may take into account financial consequences of differentiation policies of housing associations. Different policies of maintenance may be connected with possible differentiation in other services delivered by housing associations. Finally additional research is needed into the question how the purchasing policy and strategy of housing associations with regard to maintenance services could be established in order to enable differentiation and to make it a success.

For sectors outside the social housing sector, e.g. the commercial housing sector, the possibilities for customization of maintenance and therewith the application of cluster analyses may be even wider than revealed in this research for social housing. In commercial housing and the office rental sector, it is more possible for landlords to combine upgraded services and rents. Additionally, it may improve the match between the market demand and supply, and thus help reduce costs resulting from gaps. Future research may reveal and prove certain relationships.

\section{Notes}

1. WBO (Housing demand survey) is a representative sample of 120000 Dutch residents administered by the Central Bureau of Statistics.

2. Only respondents were included in the analyses with importance ratings on all possible maintenance services. This includes both Missing At Random (MAR) and Not Missing At Random (NMAR).

\section{References}

Ahlstrom, P. and Nordin, F. (2006) Problems of establishing service supply relationships: evidence from a high-tech manufacturing company. Fournal of Purchasing and Supply Management, 12(2), 75-89.

Anable, J. (2005) 'Complacent car addicts' or 'aspiring environmentalists'? Identifying travel behaviour segments using attitude theory. Transport Policy, 12, 65-78.
Baalbaki, I. and Malhotra, N.K. (1993) The marketing management bases for international market segmentation: research propositions and managerial implication. International Marketing Review, 10(1), 19-44.

Brady, M.K., Cronin, J.J. and Brand, R.R. (2002) Performance-only measurement of service quality: a replication and extension. Fournal of Business Research, 55(1), 17-31.

Cattell, R.B. (1966) The scree test for the number of components. Multivariate Behavioral Research, 1(April), 245-76.

CFV (Centraal Fonds Volkshuisvesting) (2006) Verslag Financieel Toezicht Woningcorporaties 2005, CFV, Naarden.

Chew, M.Y.L., Tan, S.S. and Kang, K.H. (2004) Building maintainability - review of the state of the art. Fournal of Architectural Engineering, 10(3), 80-7.

Da Silveira, G., Borenstein, D. and Folgliatto, F.S. (2001) Mass customization: literature review and research directions. International fournal of Production Economics, 72, 1-13.

Dogge, P. (2003) Van woningverhuurder naar aanbieder van woongenot, Technische Universiteit Eindhoven, Eindhoven.

El-Haram, M.A. and Horner, M.W. (2002) Factors affecting housing maintenance costs. Fournal of Quality in Maintenance Engineering, 8(2), 115-23.

Fornell, C. and Johnson, M.D. (1993) Differentiation as a basis for explaining customer satisfaction across industries. fournal of Economic Psychology, 14, 681-96.

Green, P.E. and Krieger, A.M. (1995) Alternative approaches to cluster based market segmentation. Fournal of the Market Research Society, 37(3), 221-39.

Hair, J.F., Anderson, R.E., Tatham, R.L. and Black, W.C. (1998) Multivariate Data Analysis, Prentice Hall, Englewood Cliffs, NJ.

Jackson, R.W. and Cooper, P.D. (1998) Unique aspects of marketing industrial services. Industrial Marketing Management, 17(2), 111-18.

Jones, K. and Sharp, M. (2007) A new performance-based process model for built asset maintenance. Facilities, 25(13/ 14), 525-35.

Lampel, J. and Mintzberg, H. (1996) Customizing customization. Sloan Management Review, 38(1), 21-30.

Mitchell, V.W. (1994) How to identify psychographic segments. Part 2. Marketing Intelligence E Planning, 12(7), 11-17.

Mossel, H.-J. van. (2008) The Purchasing of Maintenance Service Delivery in the Dutch Social Housing Sector, IOS Press, Amsterdam.

Mossel, H.-J van., Straub, A. and Jansen, S.J.T. (2006) Onderhoud en de Huurder, Habiforum, Gouda.

Parasuraman, A. (1998) Customer services in business-tobusiness markets: an agenda for research. fournal of Business $\mathcal{E}$ Industrial Marketing, 13(4/5), 309-21.

Parasuraman, A., Zeithaml, V.A. and Berry, L.L. (1985) A conceptual model of service quality and its implications for future research. Fournal of Marketing, 49(Fall), 41-50.

Parasuraman, A., Zeithaml, V.A. and Berry, L.L. (1988) SERVQUAL: a multiple-item scale for measuring consumer perceptions of service quality. Fournal of Retailing, 64(1), 12-40.

Parasuraman, A., Zeithaml, V.A. and Berry, L.L. (1991) Refinement and reassessment of the SERVQUAL scale. fournal of Retailing, 67(4), 42-50. 
Pitt, M., Goyyal, S. and Sapri, M. (2006) Innovation in facilities maintenance management. Building Service Engineering Research and Technology, 27(2), 153-64.

Punj, G.N. and Stewart, D.W. (1983) Cluster analysis in marketing research: review and suggestions for application. fournal of Marketing Research, 20(May), 134-48.

Shen, Q., Lo, K.K. and Wang, Q. (1998) Priority setting in maintenance management: a modified multi-attribute approach using analytic hierarchy process. Construction Management and Economics, 16(6), 693-702.

Sherwin, D. (2000) A review of overall models for maintenance management. Fournal of Quality in Maintenance Engineering, 6(3), 138-64.

Shohet, I.M. (2003) Building evaluation methodology for setting maintenance priorities in hospital buildings. Construction Management and Economics, 21(7), 681-92.
Tsang, A.D.C. (2002) Strategic dimensions of maintenance management. Fournal of Quality in Maintenance Engineering, 8(1), 7-39.

Van Kempen, R. and Priemus, H. (2002) Revolution in social housing in the Netherlands: possible effects of new housing policies. Urban Studies, 29(2), 237-53.

Van Mossel, J.H. and Straub, A. (2007) Procurement of Dutch housing associations technical management services: a decision framework. Property Management, 25(5), 487-501.

Wedel, M. and Kamakura, W.A. (1998) Market Segmentation: Conceptual and Methodological Foundations, Kluwer Academic Publishers, Dordrecht.

Wynstra, F., Axelsson, B. and Van der Valk, W. (2006) An application-based classification to understand buyer-supplier interaction in business services. International fournal of Service Industry Management, 17(5), 474-96. 